を使用しているため，なかなか取り組みにくい点皂ある かむ知れませんが，大変安価に出来る様ですので是非各 施設でも奏用化出来ればと思います。またIC は X線装 置にす数多く使用されて打り，乙の様な電気回路を勉強 する機会も会として検討する必要があるのではないでし ようか. またNo. 25 ではマーカプリンタをフィルムに 向かって左下につけ，使用にあたっては問題ないという 事ですが，各種装置のフィルムプリント部の位置は様々 で, ID カドの大きさ，フィルムプリント部の大きさ，

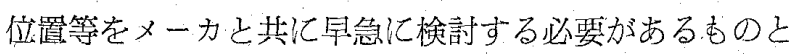
考えます。

\section{6. 連続撮影用フィルムチェンジャの比較}

\section{九州大学医学部附属病院放射線部} 田中順一：新開英秀

どのチェンジャでも遅い速度で撮影した方が解像力が 良い。また中央部と周辺部では，保とんどのチェンジャ が中央部が解像力が良い. チェンジャ間の比較は，チェ ンジャ自体よりも，その他の因子（增感紙，X線出力機 器等）が絡みあい比較ができす，とれからの問題点とし たい. チェンジャ自体の振動については，早い速度で撮 影した時大きくゆれ，また振動の大きい時に撮影してい るので，解像力低下の一因であるう. 我々は, チェンシ ヤを使用する際しのようなととを認識して撮影する必要 がある：どの装置についても言えることだが，特に血管 撮影は神経を使うので, 使いやすく, 解像力の良いチェ ンジャを望んでやまない.

\section{7. 造影剂注入速度の検討（第 2 報）}

荒尾市民病院 釜崎啓史 造影剤注入速度について, 内径 $2.4 \mathrm{~mm}$ の動脈造影を想 定し，その至適造影剂注入速度を実験により検討した. 実験孔あたり，人工血流装置を試作し，模擬血液己して 生理食塩水を，また，模擬血管としてシリコン製静脈力 テーテルを用いた。

[結論]

内径 $2.4 \mathrm{~mm}$ の血管内血流速度が $5 \sim 10 \mathrm{ml} / \mathrm{sec}$ ○ きの至適造影剤注入速度は 8 $10 \mathrm{ml} / \mathrm{sec}$ である.

28. 空気圧式自動注入器に関する 1 つのデータについて 熊本赤十字病院放射線科

○竹野俊一・北任和幸

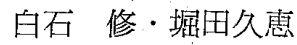

〔目的〕

注入代と流量う関係を計算で求める方法を検討したの て街告する。

〔結果】
カテーテルの両端に加わる圧力の差を直管の圧力損失 として計算し，実験デ一タと比較したが，層流・乱流に かかわらず，よく対灾しているてとがわかった。 しかし， 乱流の場合任少し計算で求めた方が圧力の傾きが急であ るという結果が出た. また自動注入器とカテーテル入口 の関係は，現在検討中であるが，影響を及ぼすファクタ について傾きが違うだけで正比例の関係であると考えら れる，以上の理由から注入王と流量の関係について計算 で近似できるのではない加と考える。

\section{座長集約 $(26 \sim 28)$ 春木正道（人吉総合病院）}

この演題群では，フィルムチェンジャの比較, 人工血 管による造影剂注入速度の基礎実験，カテーテル内部の 流量比較を検討した 3 演題である. 26 席の田中らは，同 室内同発生装置を使って，チェンジャのみの振動など諸 特性を解像才を主に調べている．27席の釡崎らは，人工 血管血流循環装置を陚作し，生理食塩水を一定量の血流 量に仮定して，造影㓮濃度，注入量などを検討してい る. 28席の竹野らは, 自動注入器の注入王力によりカテ 一テル内部の造影剂流量などを笑験的に，また数式的に 検討して，今後の自動注入器には，注入压だけでなく， 注入単位流量をコントロール可能なものが必要である う.

\section{9. 硬質塩化ビニール濃度補償F ilter について}

\section{九州厚生年金病院}

○西坂秀彦・高橋伸一 岡田寅彦・岡部健五

從来補償 Filter の村質として，Al を主に使用してき たが，種々な形状を作製するためには加工が困難であっ た。我々はいろいろな材質について検討した結果， $\mathrm{T}$ 社 製硬質塩化ビニル(以下塭ビと記す)が最す適していた。

塩ビは, Acryl に比べ粘りがあり, 軟質で加工がしや すい.また， $\mathrm{Al}$ 亿比べ約1.5倍の厚さとなり， Filter の 形状は，ゆるやかな濃度階調となる傾斜をもたせるとと ができる，更に，気泡や異物等がなく均一である.この 様に，塩ビはFilter の材質に適するという結果を得た。

我々は人体のあらゆる部位に塩ビ Filter を使用し，良 好な結果を得ている. 今後も，より多くの情報が得られ る Filter の材質の検討を行っていきたい.

\section{0. 甲状腺の軟エックス線撮影}

\section{野口病院放射線科}

原尾基継・宮原純徳・山下健二

[目的]

甲状腺腫演の石灰化沈着像の描出について，ファント ム，および，臨床例にて検討を行った。 